\title{
Collaboration in E-Learning: A Study Using the Flexible E-Learning Framework
}

\author{
C. Vandenhouten \\ S. Gallagher-Lepak \\ J. Reilly \\ University of Wisconsin- Green Bay \\ P. Ralston-Berg \\ Penn State World Campus
}

\begin{abstract}
E-Learning remains a new frontier for many faculty. When compared to the traditional classroom, ELearning requires the talents of many team members from a variety of departments as well as the use of different teaching and learning strategies. Pedagogy as well as team configurations must change when moving to the online environment. As a result, collaboration is a key component in creating quality ELearning. This article describes the results of a faculty survey based on the Flexible Framework for ELearning. The authors developed a survey to capture faculty perceptions of E-Learning dimensions. Using a descriptive design, the authors surveyed participating faculty $(\mathrm{N}=45)$ from several Midwestern campuses during a year-long faculty development program on E-Learning. Items related to the ELearning dimension being discussed during the monthly videoconference were distributed prior to the monthly video sessions to assess faculty understanding of the E-Learning dimensions. The project was designed to foster a deeper understanding of E-Learning dimensions and of collaborative roles and activities necessary for E-Learning.
\end{abstract}

\section{Introduction}

E-Learning in higher education is a team endeavor. In contrast to traditional face-to-face programs, E-Learning requires a wider network of collaboration among all professionals involved (instructors, instructional designers, technology support staff, etc.). An instructional designer, for example, who seeks to improve interface design in an E-Learning program may encourage faculty to structure their courses using a consistent interface template. This simple interaction between the instructional designer and faculty enhances ease of use for students by creating a more consistent course appearance across the program.

One E-Learning framework that can foster collaboration among E-Learning professionals is the Flexible E-Learning Framework (Khan, 2005). The framework provides an organizing structure to understand E-Learning perspectives within the following eight dimensions: pedagogy, technology, interface design, evaluation, management, resource support, ethics and institution (Khan, 2005). ELearning professionals need to understand all eight dimensions and be cognizant that specific roles and 
responsibilities are dependent upon the combination of select dimensions to a greater or lesser degree. For example, instructors may be most involved with the E-Learning dimensions of pedagogy, evaluation, technology, and ethics. In contrast, instructional technology specialists may more heavily participate in the technology, interface design, and resource support dimensions. Using this framework, it is easy to recognize that no one professional has exclusive coverage over all dimensions of E-Learning. Quality ELearning occurs when there is sufficient overlap of roles across dimensions, expert professionals filling those roles, and good communication among professionals enacting their roles.

\section{Faculty Development to Enhance Understanding of E-Learning Dimensions and Collaboration}

Five University of Wisconsin (UW) System Schools of Nursing have offered a fully online, collaborative RN to BSN program called BSN@Home for over nineteen years. As part of this program, the five UW schools were involved in a Wisconsin Technology Enhanced Collaborative Nursing Education (WITECNE) five-year grant (2006-2011) designed to infuse technology into nursing education (US Department of Health \& Human Services, Health Resources \& Services Administration [HRSA] Project \#U1KHP07714). Beginning in 2006, each UW School of Nursing led a year-long faculty development program across five campuses, with a unique focus on instructional technology (i.e., simulation learning, problem-based learning, telehealth, virtual worlds [Second Life®], and E-Learning). Each UW campus had a site leader who encouraged participation and maintained regular communication with their campus scholars regarding scheduled videoconferences and available resources. A total of 150 scholars participated across the five-year grant, including nursing faculty and non-faculty (e.g., instructional designers) representing each of the five UW nursing schools and the Wisconsin Technical College system, tribal and private colleges.

This article describes the outcome of the fifth and final year of the grant hosted by the UW-Green Bay Professional Program in Nursing with a focus on faculty development on E-Learning. A multidisciplinary planning group of nine members (e.g., nursing educators, instructional technologists, outreach specialist) considered various approaches, models, and topics in planning the year-long ELearning faculty development program. They recognized the focus of E-Learning at the institutional level often becomes the technologies that also a major emphasis of faculty development for online teaching/learning. The planning group wanted the E-Learning year to be about more than simply using a specific technology in nursing education. The group recognized that a comprehensive view of ELearning, as reflected in the Flexible E-Learning Framework (Khan, 2005), could guide the development of a survey and guide the design of the monthly videoconference topics throughout the faculty development year.

The year-long program consisted of six monthly videoconferences, an online course to deliver content, and development of surveys corresponding to monthly videoconference topics (Reilly, Vandenhouten, Gallagher-Lepak, \& Ralston-Berg, 2012). The purpose of the project was twofold: 1) to provide a faculty development program on E-Learning using the Flexible E-Learning framework, and 2) to describe faculty perceptions regarding the dimensions of E-Learning and the collaborative nature of ELearning. By understanding the dimensions of E-Learning (parts), it was anticipated that faculty would gain a deeper understanding of E-Learning (whole) and the necessity of collaboration among E-Learning professionals in the design and delivery of online courses.

\section{Background}

\section{E-Learning Roles and Collaboration}

The function of E-Learning development teams are often described in the literature through distinct roles and tasks. For example, instructional designers are often characterized as being in a support 
role to content experts, E-Learning program managers are often described in administrative roles beyond that of development, and there exists a wide separation in general between administration of E-Learning and those dedicated to E-Learning design and development (Meyer \& Barefield, 2010; Reid, 1999). However, Khan's dimensions of E-Learning suggest an overlap of roles and responsibilities and the need for collaboration within an institution. Table 1 depicts the eight roles within the Flexible E-Learning Framework. In the Flexible E-Learning Framework, individual professionals both within and at times outside of an institution must communicate, interact, and share ideas to address all aspects of E-Learning (Khan, 2005).

Table 1 Dimensions of E-Learning and Professional Roles

\begin{tabular}{|l|l|}
\hline $\begin{array}{l}\text { Dimensions of E- } \\
\text { Learning }\end{array}$ & E-Learning Roles \\
\hline Pedagogy & Faculty, instructional designers \\
\hline Technology & $\begin{array}{l}\text { Information technology staff (IT), LMS administrators, instructional } \\
\text { technologists, multimedia specialists, production specialists, faculty }\end{array}$ \\
\hline Evaluation & $\begin{array}{l}\text { Faculty, instructional designers, evaluation specialists, quality assurance } \\
\text { staff, editors, researchers }\end{array}$ \\
\hline Management & $\begin{array}{l}\text { Program manager, academic department manager, project manager, } \\
\text { department / team manager, textbook management staff }\end{array}$ \\
\hline Resource Support & Technical support staff, production specialists (tip sheets, tutorials) \\
\hline Ethics & $\begin{array}{l}\text { Administrators, faculty, academic integrity officers, copyright assurance } \\
\text { staff, researchers }\end{array}$ \\
\hline Institutional & $\begin{array}{l}\text { Administrators, academic affairs staff, student services staff, faculty } \\
\text { development staff, intellectual property agreements, librarians }\end{array}$ \\
\hline Interface Design & $\begin{array}{l}\text { Instructional designers, graphic designers, web designers, usability and } \\
\text { accessibility specialists }\end{array}$ \\
\hline
\end{tabular}

Sources: Grant, 2012; Khan, 2004; Khan, 2005; Ralston-Berg \& Gordy, 2002; Ralston-Berg, McCaffrey, \& Kmetz, 2012.

Collaboration, or how these professionals work together, must be considered when configuring ELearning teams and roles. Awareness of roles is a key component, but for true collaboration, team members need a deeper understanding. Breaking down silos and educating all team members on what others do, how they do it, and how professionals in different roles can work together effectively sets the stage for collaboration. This level of understanding often requires a refinement and adjustment of how faculty think about each other as well as expectations (Davis, Little, \& Stewart, 2004).

Collaboration permeates every stage of the E-Learning process: from planning and development to the evaluation and ongoing support of online programs. When members of a team collaborate, they "share their expertise such that emergent ideas/designs are created and no one member can claim ownership.” This in turn results in a higher quality product (Aleckson, 2010, p. 2). It is the person in the administrative role that sets expectations for the faculty-designer team and determines how collaborative the relationship between faculty, designers, and other staff will be. Management influences collaboration by communicating administrative expectations and values, clarifying roles of specialists selected to work on a project, supporting a structured process that allows time for collaboration, and supporting an evaluation plan that allows reflection, review, and revision. Although experts working independently within a process can impact quality, this practice usually involves a division of labor which does not 
maximize the potential for quality (Bates, 2007; Dziuban, Hartman, Moskal, Sorg, \& Truman, 2004; Ellis \& Phelps, 2000; Meyer \& Barefield, 2010). Promoting collaboration is just as important to success as employing necessary key staff or implementing a structured process (Bates, 2007; Ellis \& Phelps, 2000).

Communication and sharing over distances often occurs within E-Learning collaboration. Team members may use videoconferencing, web conferencing, telephone communication, email, or shared online documents. Whatever the means, it is important that resources are available for support, all team members have shared access and materials can be shared equally between all team members (Aleckson \& Ralston-Berg, 2011; Ellis \& Phelps, 2000).

\section{Knowledge and Reflection Needed for Faculty to Collaborate in E-Learning}

In many institutions, instructional design and development teams appear more adept at collaboration than faculty, who may still be transitioning to online teaching and less aware of the benefits of collaboration in E-Learning. Ellis and Phelps (2000) describe this transition for faculty as moving from working in isolation to working with teams of people with unique skills. In cross-team E-Learning development, faculty need to know not only the players and their roles, but also how they as content experts can support the team to design effective E-Learning courses (Deubel, 2003; Ellis \& Phelps, 2000; Reid, 1999). Ellis and Phelps describe the need for a systems approach to assist faculty as they transition through collaboration, faculty development, and change management. One exemplar of a systems approach that helps assure quality in E-Learning is the Quality Matters ${ }^{\mathrm{TM}}$ Program, which is a facultycentered, peer review process that engages an interdisciplinary team for continuous E-Learning course improvement (Quality Matters, 2013). Another exemplar noted in the literature uses an open systems framework to evaluate pedagogy, management, and evaluation in E-Learning programs (Rovai, 2003). Rovai's open systems approach is similar to the dimensions in the Khan Flexible E-Learning Framework.

Making the transition involves increasing knowledge of the unique skills and contributions team members can make to E-Learning as well as reflecting on one's own role in the E-Learning process. Several tools that enhance faculty reflection on E-Learning are described in the literature. Sikl-Daniell, Williams and Wong (2006) used two tools for online adjunct faculty evaluation at U21Global, an online graduate school owned by 17 international universities. The first tool allowed adjunct faculty a chance to voice their perspective on E-Learning issues such as workload, pedagogical and technological support, and overall experience of online teaching. The second tool provided opportunities for two-way communication, starting with the mentor and students giving feedback to the adjunct faculty member. The adjunct faculty member was encouraged to reflect and respond in writing on how to approach things differently in future online courses. This process was guided by the premise that quality adjunct instructors are retained through quality faculty support, as found by Schnitzer and Crosby (2003).

Another self-reflection tool found in the literature was a rubric designed to allow online faculty at an Australian university to self-reflect on and self-evaluate their course development and online teaching skills (Northcote, Seddon, \& Brown, 2011). The rubric was designed to provide a benchmark through which online teaching by academic staff at all levels of expertise could be gauged. The rubric includes descriptive statements designed to identify knowledge and skills associated with effective online teaching and course design based on three main areas: content, technology, and pedagogy (Northcote et al., 2011). While these tools address some aspects of E-Learning, the need for a more comprehensive process of reflection on E-Learning for faculty was identified.

\section{Methods}

A descriptive design was used to assess faculty perceptions of E-Learning dimensions and collaboration. Participants were nursing faculty, hereafter referred to as scholars, from each of the five UW nursing schools (UW-Eau Claire, UW-Green Bay, UW-Madison [principal investigator], UWMilwaukee, and UW-Oshkosh), one nursing program representing the Wisconsin Technical College system, one tribal institution, and one private college. Scholars were invited and/or selected by their 
institution to participate in a year-long faculty development program related to E-Learning. In total, 45 nursing faculty participated in the faculty development program.

To overcome the distance between the five UW campuses, the structure of the year-long faculty development program consisted of monthly videoconferences designed to engage scholars in one of the E-Learning dimensions. Videoconference sessions were one hour in duration, and took place on a consistent day and time. While this served to provide consistency in scheduling, faculty whose teaching schedules conflicted were unable to participate in the monthly sessions. Faculty were introduced to the Flexible E-Learning Framework by the author, Dr. Badrul Khan, during the first videoconference. The remaining sessions engaged scholars in a discussion about some aspect of the E-Learning dimensions. For example, during the videoconference on the management dimension, faculty scholars discussed the structure and roles of collaborative work teams and how to maximize available resources to deliver ELearning.

Resources were uploaded for each of the eight dimensions of the Khan framework and were provided to participants via an online Desire2Learn@ (D2L) course. Faculty scholars were encouraged to participate in reflective discussions, both online and during the monthly videoconferences prior to and following the sessions.

\section{Survey Design}

The authors recognized that a comprehensive view of E-Learning would be helpful to faculty in understanding roles, functions, and collaborative activities in E-Learning. The survey was not intended to assess participant's reaction to the content of the monthly videoconferences but rather to determine their understanding of the E-Learning dimensions. The Khan Flexible E-Learning Framework included over 600 items corresponding to the eight dimensions of the Flexible E-Learning Framework to assist those involved in the E-Learning process to understand aspects of E-Learning in a comprehensive way (Khan, 2005, p. 13). Understanding the limits on faculty time, a limited number of Khan's items from each of the dimensions were selected and/or adapted (10-15 items per dimension) for a survey designed to determine faculty awareness of the collaborative nature of E-Learning, roles, activities and processes. Items were selected with particular emphasis on their relevance to online teaching and the scope of faculty involvement in E-Learning. Items were reviewed by outside experts with expertise in online course design, education program evaluation, and E-Learning to ensure that dimensions were sufficiently represented.

For example, Khan's institutional dimension checklist included 144 items addressing readiness to implement E-Learning, organization and change, budgeting and return on investment, partnerships, program and course information, marketing and recruitment, admissions, financial aid, registration, online program entry, program delivery, student services, and intellectual property. From this extensive list of items, 14 items were chosen to represent the institutional dimension. Selected items were further refined and reviewed by outside experts with expertise in online course design, education program evaluation, and E-Learning to ensure dimensions were sufficiently represented.

The final survey created by the authors was composed of 95 items using primarily open-ended and Likerttype responses. Items were divided into six separate online surveys corresponding to the dimension covered during the monthly videoconferences. An interactive website with sample survey items can be found at http://www.uwgb.edu/witecne/.

\section{Procedure}

Following institutional review board approval, 45 faculty scholars received an e-mail invitation to the monthly online survey with items corresponding to the topic of videoconference. Participants received the link to a consent form and online survey just prior to the six videoconferences. Participants were able to access the online surveys at their convenience from any Internet-connected computer. Reminders were sent to non-responders at regular intervals. Participation was encouraged by an incentive drawing for educational technology prizes for those completing all online surveys over the faculty development year. 


\section{Findings}

Survey response rates varied and are reported for each dimension below. Response rates varied from a high of 40 participants (89\%) responding to the survey related to the pedagogical dimension of ELearning to a low of 17 (38\%) responding to the survey on the institutional dimension. Levels of participation may reflect scholars' perceived relevance, comfort, and knowledge of the dimensions. Approximately $60 \%$ of scholars were experienced online educators. It was anticipated that participation in monthly surveys would drop as the year progressed for a variety of reasons, not the least of which included survey fatigue, faculty workload, or other demands on time. While it is beyond the scope of this article to include all results, several interesting findings follow reported by dimension and the number of scholars who responded.

\section{Pedagogy Dimension ( $\mathrm{n}=40)$}

Forty of the 45 scholars completed the electronic survey related to the Pedagogical dimension of E-Learning. Survey items addressed topics germane to this dimension including content design, learner needs and goals in the design, and organization of E-Learning strategies. Six out of ten scholars indicated they employ a combination of faculty-centered and student-centered approaches to learning. Strategies used to allow students some control over the material to be learned included choosing topics for course projects (69\%), composing discussion questions (46\%), flexible due dates (35\%), selecting own work groups (27\%), and negotiating learning goals (19\%). Fifteen scholars (38\%) indicated they surveyed students regarding what they expect to learn or gain from the online course. When asked about the degree to which course assignments and discussions are flexible enough to accommodate students' learning goals, the large majority (83.6\% endorsed very much or somewhat) felt their course(s) allowed for this flexibility. Types of multimedia used included video clips (68\%), YouTube video links (48\%), synchronous chat (18\%), podcasts (35\%), Second-life ${ }^{\odot}$ activities (13\%), and other (30\%) including voiceover lectures, wikis, case studies, and simulations. Teaching strategies used most often in online courses were asynchronous discussions (84\%), followed by case studies (66\%), online presentations (46\%), simulation (33\%), and role playing (30\%). Strategies used less often included online games (22\%), synchronous discussions (22\%), debate (16\%), and virtual exhibits (14\%). In terms of instructional and technical effectiveness, most strategies were perceived as good or excellent by scholars (71\% and $100 \%$, respectively).

\section{Technology Dimension (n=31)}

The technological dimension of E-Learning included issues of planning the physical and digital infrastructure (hardware and software) needed to deliver E-Learning courses. Reliable and adaptable infrastructure is required of the institution including hardware (e.g., computers, servers, networking devices) and software (e.g., word processers, e-mail, learning management systems) as well as competent technical staff (Khan, 2005). The majority of scholars (46\%) were unaware of their institution's technology plan. In response to the question regarding whether cost of technology was a deterrent to taking an E-Learning course, over half (57\%) of the respondents did not feel cost was a deterrent and indicated the institution provided special pricing to students for needed hardware and software (71\%). Half indicated their institution provided links to resources for the required hardware and software and an orientation program that provided technical training to students prior to enrolling in online courses.

\section{Evaluation Dimension $(\mathbf{n}=38)$}

The evaluation dimension of E-Learning includes items related to evaluation of people (e.g., ELearning team members and students), processes (e.g., the design and evaluation of online courses), and products (e.g., course materials). Items chosen focused on assessment methods used by faculty to evaluate student learning, deter academic misconduct, and elicit student feedback on course content. All scholars indicated that students were given the opportunity to evaluate courses with the following methods used: instant feedback (15\%), mid-semester feedback (18\%), end of semester feedback (94\%). A wide array of individual and group assignments were employed to assess learners including online 
assignments (79\%), group projects (61\%), individual projects (48\%), case studies (36\%), quizzes (27\%), journals or web blogs (24\%), and online presentations (24\%). Instructor feedback was primarily delivered via feedback in the gradebook or Dropbox (94\%). The majority (78\%) of faculty indicated they impose a penalty for late work. In addition to instructor evaluation of student learning, other evaluation methods included self (42\%), peer (36\%), and group evaluation (27\%). Strategies used to reduce academic misconduct (e.g., students work is their own) included time limits (45\%), assigning different topics (42\%), randomizing test items (36\%), plagiarism checking software (36\%), proctored online exams (30\%), and student signature on an academic honesty statement (12\%).

\section{Management Dimension (n=21)}

The management dimension refers to managing the stages of E-Learning content and resources. This can be divided into two phases: content delivery and maintenance. Depending on the scope of the project and size of the institution, the number and type of team members involved in the development of online courses can vary. Examples of team members include instructional designer, content expert, and project manager. The majority of scholars felt support services were well coordinated with one scholar stating "the learning support staff was involved at all phases of course development, supplying expertise for instructors developing new courses." Yet another scholar indicated support services were "not well coordinated and that a person has to be assertive and determined about seeking help as needed." Other management areas included tutoring services, copyright issues, and notices about course modifications (faculty and student). Scholars reported tutoring services were provided through live chat as well as email. Over half (53\%) of scholars were unaware of who was responsible to acquire and renew copyright permissions with learning materials, with library staff identified most often. Finally, a variety of methods were used by scholars to notify students of news and changes including course announcements, message boards, email, and Skype.

\section{Resource Support Dimension (n=38)}

The resource support dimension involves online support resources required to deliver meaningful learning environments (Khan, 2005). Types of online support for students identified by scholars included training on how to access online library services (61\%), non-instructor assistance with E-Learning tasks (41\%), and frequently asked questions (FAQs) sections for students (38\%). Scholars provided guidance to students on how to send e-mail attachments (65\%), upload or download files (65\%), open files in email (52\%), attach pictures (39\%), install software (35\%), and create online presentations (26\%). Telephone, live chat, and email support for distance learners were available. Email was the primary link for tech support, tutoring services, library services, admissions, and the bookstore. Resources primarily provided via phone included registration, bursar, and financial aid.

\section{Ethics Dimension ( $\mathbf{n}=\mathbf{2 6})$}

Ethical considerations of E-Learning come from a wide array of topics including social political influences; geographic; learner and cultural diversity; the digital divide; and legal issues. Scholars identified several ethical issues including academic misconduct (e.g., plagiarism, "individual vs. collaborative” work), socioeconomic issues (hardware/Internet access, learning preferences, privacy issues, social skills, and personal biases of students), and political issues (e.g., polarizing health policy, personal political beliefs). Eight out of ten scholars identified strategies for presenting viewpoints on controversial issues including a variety of resources from different perspectives, use of debates, and identification of pro and con formats. Disability issues in E-Learning were particularly challenging for students experiencing visual, mobility, and hearing challenges. Accommodations identified by scholars included allowing extra time for exams, tutoring services, and providing transcripts of audio materials. Another issue specifically challenging in the E-Learning environment is sensitivity to student location (i.e., students residing in different time zones). Scholars identified strategies in E-Learning courses such as use of asynchronous discussions and a specific time (midnight) for consistent due dates. 


\section{Institutional Dimension ( $\mathbf{n = 1 7})$}

The institutional dimension included administrative affairs (e.g., needs/readiness assessment, budgeting and return-on-investment, partnerships with other institutions, marketing and recruitment, admissions, financial aid), academic affairs (e.g., accreditation, instructional quality, faculty and staff support workload, compensation) and student services (e.g., pre-enrollment services, advising, services for students with disabilities, library support) (Khan, 2005). Scholars identified perceived strengths as supportive media, design specialists, and regular platform (D2L) upgrades. Identified weaknesses included feeling unprepared for the system upgrade, differences in departmental support for E-Learning, and lack of 24-hour technology support for students. When asked about budgets for E-Learning, marketing for online programs, institutional policies regarding intellectual property rights, and partnerships with other institutions for shared resources (online library, bookstores, etc.), the majority of scholars responded they were unsure suggesting they are less aware of institutional resources than perhaps the other dimensions.

\section{Interface Design Dimension}

Interface design issues involve the overall look and feel of an E-Learning program, including content organization, accessibility, and navigation (Khan, 2005). Interface design was not evaluated directly through a monthly survey but rather by consultants with expertise in E-Learning design and nursing education and then shared with scholars. Consultants designed and applied an interface design rubric, based on Khan's E-Learning framework (2005) and contemporary learning theories, to each of the six core nursing courses in the BSN@Home program. Such outside review was important to evaluate consistency and ease of online course navigation for students since each of the core courses was designed and developed by a different UW School of Nursing. A major finding of the interface design evaluation was the need for a consistent online course design across the BSN@Home program. Often the course design mimicked the design of an individual campus template instead of one design applied to all BSN@Home courses. Evaluation categories in the rubric included (a) coherence and consistency between and within courses, (b) content management, (c) learner engagement, and (d) curriculum design (Tyczkowski, Bauman, Gallagher-Lepak, Vandenhouten, \& Reilly, 2012, p. 291). Findings of the review offered both "quick fixes" to courses as well as more involved fixes requiring additional time and effort to implement. Examples of "quick fixes" included greater consistency in a variety of course elements such as the location of materials in course syllabi (e.g., text or other readings, videos, websites), consistent format for identifying course assessment strategies (i.e., locate on grades page), and use of a rubric for evaluating online discussions. More involved fixes included the need for a stronger brand presence for the BSN@Home collaborative program and improved consistency in course structure to improve the overall experience for the learner. One possible strategy to improve consistency in course structure involved establishing a single point of entry for all e-materials possibly linked through a centralized database. Other suggestions included greater transparency in identifying assignments requiring research, refining group activities to provide skill building in collaboration and consensus building, and use of a standard grading scale in all courses.

\section{Collaboration and E-Learning Roles}

This project involved the nursing programs at the UW campuses of Eau Claire, Green Bay, Madison, Milwaukee, and Oshkosh. These nursing campuses collaborate to deliver an innovative distance education program, the BSN@Home program. While the nursing curriculum and teaching responsibilities for this online program are shared among the nursing campuses, each is responsible to take the lead for one of the five required core courses in the collaborative program. Elective courses are shared among the campuses. A collaborative approach is critical to the success of a shared program.

The survey incorporates aspects of collaboration necessary in E-Learning. Select items and results related to collaboration among E-Learning professionals are provided in Table 2. These items (as well as other items in the survey) address roles among e-learning professionals, issues addressed by several roles, and how E-learning professionals work in complementary and interdependent ways. 
Table 2 Sample Items and Results related to E-Learning Roles and Collaboration

\begin{tabular}{|c|c|}
\hline Sample Items & Results \\
\hline $\begin{array}{l}\text { What is the predominant role in the online } \\
\text { course you teach (check all that apply)? } \\
\text {-domain expert } \\
\text {-facilitator } \\
\text {-coach } \\
\text {-mentor } \\
\text {-eclectic } \\
\text {-not sure } \\
\text {-other, please specify }\end{array}$ & $\begin{array}{c}\%(n) \\
38 \%(15) \\
80 \%(32) \\
35 \%(14) \\
25 \%(10) \\
8 \%(3) \\
8 \%(3) \\
5 \%(2) \\
\end{array}$ \\
\hline $\begin{array}{l}\text { Does the course have orientation programs } \\
\text { that provide technical training to students } \\
\text { before starting the course? } \\
- \text {-Yes } \\
\text {-No }\end{array}$ & $\begin{array}{c}\%(n) \\
50 \%(14) \\
43 \%(12)\end{array}$ \\
\hline $\begin{array}{l}\text { What clearly defined roles exist for E- } \\
\text { Learning support? (Select all that apply) } \\
\text {-Project Managers } \\
\text {-Instructional Designers } \\
\text {-Editors } \\
\text {-Interface Designers } \\
\text {-Course Developers } \\
\text {-Graphic Artists } \\
\text {-Media Production Specialists } \\
\text {-Programmers } \\
\text {-Webmasters/ Course Management System } \\
\text { Administrators } \\
\text {-other (content experts) }\end{array}$ & $\begin{array}{c}\%(\mathbf{n}) \\
11 \%(2) \\
58 \%(11) \\
16 \%(3) \\
16 \%(3) \\
37 \%(7) \\
11 \%(2) \\
32 \%(6) \\
21 \%(4) \\
47 \%(9) \\
21 \%(4)\end{array}$ \\
\hline $\begin{array}{l}\text { Does the E-Learning budget allow for } \\
\text { support staff? } \\
\text {-Yes } \\
\text {-No } \\
\text {-I don't know }\end{array}$ & $\begin{array}{c}\%(n) \\
28 \%(5) \\
44 \%(8) \\
28 \%(5)\end{array}$ \\
\hline $\begin{array}{l}\text { How frequently do students ask technology } \\
\text { related questions of faculty? } \\
\text {-Frequently (daily) } \\
\text {-Seldom (2-3 times/wk.) } \\
\text {-Rarely ( } \leq \text { once/wk.) } \\
\text {-Never }\end{array}$ & $\begin{array}{c}\%(n) \\
12 \%(4) \\
42 \%(14) \\
45 \%(15) \\
0 \%(0)\end{array}$ \\
\hline $\begin{array}{l}\text { In what ways has Senior Administration } \\
\text { been supportive of and made financial and } \\
\text { other resources available to implement E- } \\
\text { Learning? }\end{array}$ & $\begin{array}{l}\text { Responses: Participation in grant activities, support to } \\
\text { faculty when new to E-Learning, media specialist } \\
\text { support hired, not sure/aware of any additional } \\
\text { resources }\end{array}$ \\
\hline
\end{tabular}




\begin{tabular}{|l|l|}
\hline $\begin{array}{l}\text { Describe methods, materials, and staffing } \\
\text { used to recruit online students. }\end{array}$ & $\begin{array}{l}\text { Majority of scholars were unsure or unaware of how } \\
\text { students are recruited; 3 scholars were aware of } \\
\text { marketing approaches at their institution. }\end{array}$ \\
\hline $\begin{array}{l}\text { Describe the institution's strengths and } \\
\text { weaknesses in assembling qualified staff, } \\
\text { internet access and equipment necessary to } \\
\text { support faculty and student success to } \\
\text { ensure successful E-Learning. }\end{array}$ & $\begin{array}{l}\text { Identified strengths included regular course platform } \\
\text { upgrades, technical support, knowledgeable \& } \\
\text { supportive instructional design staff, and access to } \\
\text { hardware. }\end{array}$ \\
& $\begin{array}{l}\text { Weaknesses included lack of wireless access, feeling } \\
\text { unprepared for course platform upgrades, lack of } 24 \\
\text { hour technical support for students and faculty, } \\
\text { insufficient budget and staff support for course design } \\
\text { and development, and lack of time to develop online } \\
\text { courses }\end{array}$ \\
\hline
\end{tabular}

\section{Disseminating the Findings of the Year-Long Faculty Development Program}

Results of the monthly surveys were collated and presented at an end-of-year conference. Written copies including the aggregate results of their scholars' responses to the survey were provided to each of the five nursing programs. It was hoped that these would be used to engage scholars in further exploration of E-Learning issues beyond the year-long faculty development program. A plenary conference session presented by the interface design consultants reviewed results of their evaluation and suggestions. This gave faculty the opportunity to learn important elements of interface design and strategies for improving the interface design elements of the BSN@Home curriculum.

Scholars evaluated the impact of their participation in the E-Learning year on their understanding of E-Learning issues. Ninety-five percent of scholars indicated their participation had a moderate to substantial impact (based on a 5-point Likert-type scale) on their understanding of E-Learning issues $($ mean $=4.40)$. Specific examples of how they applied new knowledge of E-Learning to their teaching, research, or outreach included the use of a self-directed readiness tool for students, tools for engaging learners with learning content such as use of student cafes, case builder software, and e-portfolios. One scholar described recruiting other faculty to increase involvement in E-Learning in his/her institution. Scholars were also asked to describe ways they planned to apply new E-Learning knowledge, attitudes, or skills to teaching, research, and/or outreach in the future. Many scholars noted they planned to adopt a new electronic health record (EHR) in their courses to enhance student use of healthcare technologies. Other plans for applying E-Learning included additional use of e-technology such as incorporation of plagiarism detection software, Wiki's, Twitter, gaming, podcasts, and case scenarios. Finally, one scholar noted he/she would integrate new technology not for its own sake but to support learning outcomes and to appeal to a variety of learners.

\section{Discussion and Implications}

Findings of the monthly surveys indicate faculty scholars were aware of pedagogical, resource, evaluation, ethical, and resource support E-Learning issues. The most common pedagogical strategies employed were discussions, case studies, and presentations. As evident by the sharing and exposure throughout the year-long faculty development program, collaboration can bring new pedagogy, strategy, ideas, and technology tools into E-Learning design and development. End of semester feedback from students is the most prevalent form of evaluation. Feedback gathered throughout the E-Learning process can be used as a source of feedback and improvement for faculty. This type of iterative evaluation may include feedback from peers, self, or students. 
Responses to the monthly surveys for the institutional, technological, and management dimensions of E-Learning revealed that scholars were less aware of these dimensions and the impact of these dimensions on their faculty role. This may indicate a need for better communication between the silos of teaching and learning (pedagogical) with those of technological and institutional. For work within larger collaborative teams across institutions, team members need consistent messages, support, and common goals to work toward. Administrators and managers can influence the degree to which collaboration takes place through expectations, values, and common goals defined and shared with ELearning teams. They also influence the process, which allows time for collaboration and iterative evaluation. It is not sufficient to create an E-Learning team or a task force. There needs to be a larger process which includes common goals, a communication plan, and a formal evaluation component to support the team.

Administrative support, essential to successful online course development and delivery, was also critical to the success of this year-long faculty development program. A greater understanding of their roles and the common goals shared among all team members encourages collaboration between faculty and management.

Persistence, flexibility, and a clear commitment by UW nursing programs were key to the success of this project. The knowledge gained allowed scholars to push past "what is" and bring innovation to their current practices while expanding collaboration to include others. Using a more comprehensive framework or plan as a guide for faculty development programs can foster collaboration within ELearning teams. Collaboration opens opportunities to learn and interact with unfamiliar units. Without some sort of guide or framework outlining all aspects of E-Learning development, faculty development program planners may omit or minimize dimensions necessary for success. For example, during this yearlong program scholars expanded their knowledge and are now able to distinguish tasks associated with different support roles and also proactively work toward more effective interface design.

Future research regarding collaborative approaches to the design and delivery of online courses is needed to better understand the faculty's comprehension of the E-Learning dimensions and need for collaboration. Of particular interest is the alignment between faculty development programs and collaboration within larger E-Learning teams. Can faculty development programs be tailored to increase faculty efficacy within highly skilled teams of professionals? Also, as faculty work in teams with other professionals, what is the impact of a formal framework on the success of that team?

\section{Limitations}

The aim of this project was to understand faculty perspectives of E-Learning and to deepen understanding of E-Learning and its unique collaborative roles and activities. As was mentioned earlier, the focus of this study was not to assess participants' reactions to the content of the monthly videoconference but rather to determine faculty understanding of the E-Learning dimensions. Not surprisingly, participation declined with each subsequent monthly survey throughout the year. We attribute this to multiple factors, including faculty workloads, survey fatigue, and possibly faculty interest in the E-Learning dimension topic for the month (i.e., 89\% response rate to the pedagogical dimension topic offered in the first month vs. 38\% response to institutional dimension discussed in the last month).

The author-designed instrument included items adopted and adapted from a comprehensive Flexible E-Learning Framework by Khan (2005). Content validity of survey items was assessed by ELearning experts as well as experienced online faculty to ensure dimensions were sufficiently represented. Reliability of the survey instrument was not conducted.

Findings represent the perceptions of faculty from a large state public university system, as well as faculty from one private and one tribal institution. While not generalizable, these data posit important perspectives and understandings of E-Learning from nursing faculty across one Midwestern state system. Further, faculty development based on this E-Learning framework, use of the survey (or similar modifications of the Khan items) is encouraged among other E-Learning programs. 


\section{Conclusion}

Overall, participants were interested in E-Learning content but had difficulty on some occasions preparing for and/or attending videoconferences due to teaching and other responsibilities. Faculty took on the role of "learners" in the faculty development program. Similar to the experiences of online students, some faculty expressed feelings of uncertainty, frustration and inadequacy in dealing with new educational technologies and social media (e.g., Twitter, Polleverywhere) used during the webinars. Results of this study suggest faculty are more familiar with aspects of E-Learning that involve course development and design. Faculty employ a wide array of student-centered teaching/learning strategies designed to engage the learner. Faculty expressed less certainty around issues related to E-Learning dimensions of institutional, administrative, and management.

Faculty need ongoing professional development in E-Learning, especially since technology changes rapidly and students are increasingly more tech savvy. The transition to E-Learning for faculty is more than a pedagogical shift and the incorporation of new technologies. It is a paradigm shift on several levels. The literature has documented well the shift in role from "sage on the stage" to "guide on the side" (Young, 1997). Similarly, there is a shift from what Bates (1997) defined as "lone ranger" to being part of a "superhero team" which has been much less emphasized. The solo approach to development and delivery of courses used in traditional F2F settings no longer applies in the E-Learning environment. Consultation and collaboration with other E-Learning professionals are needed by faculty to build and deliver quality E-Learning.

It takes “a superhero team” to deliver and protect quality in E-Learning programs. The network of E-Learning professionals can range from faculty and instructional designers to graphic designers, information technology staff, and program managers. More attention needs to be given to how E-Learning professionals in different roles work together. Such questions are new to faculty who have traditionally handled most aspects of teaching and learning on their own. Similarly, collaboration (e.g., working with a team perspective) may be new to faculty.

The literature is sparse in addressing how faculty transition from solo to team players in ELearning. Using the Dimensions of Faculty E-Learning Survey based on the Flexible E-Learning Framework, faculty can develop a more comprehensive perspective of E-Learning and better understand roles, processes, activities, and issues that are part of E-Learning. This knowledge will help faculty in collaborating with other E-Learning professionals. The survey dimensions (e.g., technological, institutional) provide a shared language as well as talking points to facilitate discussions and enhanced collaboration. The Khan Flexible E-Learning Framework (2005) has been successfully used in multiple cultures and disciplines across the globe.

E-Learning, and roles within E-Learning, will continue to evolve. Faculty and other professionals in ELearning need to understand the major paradigm shifts in moving from F2F to the online classroom to be most effective in their roles.

\section{About the Authors}

Christine Vandenhouten is an Associate Professor at the University of Wisconsin (UW)-Green Bay. Her PhD in Nursing is from Marquette University, Milwaukee WI. She has extensive experience in nursing education including program evaluation and assessment of student learning. Dr. Vandenhouten received funding to develop a poverty simulation in second life and facilitated the evaluation of the ELearning year. Her research interests include nursing education, public health nursing, health policy, and political involvement of nurses.

Susan Gallagher-Lepak is an Associate Professor and Chair of Nursing at the University of Wisconsin (UW) -Green Bay. She received her PhD in Rehabilitation Psychology from UW-Madison. She is a Licensed Psychologist and Registered Nurse. Areas of current professional writing and research include E-Learning, case-based learning, and development of an electronic nursing diagnosis clinical support tool. 
Janet Reilly is an Associate Professor at the University of Wisconsin (UW) -Green Bay and has taught and developed online RN to BSN and graduate nursing courses for ten years. She coordinated the team responsible for the year of faculty development for faculty from five UW System Schools of Nursing on E-Learning (see WI TECNE at: http://research.son.wisc.edu/tecne/year5.htm). Earning a DNP from Case Western Reserve University in Cleveland, the focus of her doctoral and subsequent research is the scholarship of online teaching and learning.

Penny Ralston-Berg, M.S., has been designing online courses since 1997. She has also served as a technology trainer and design consultant for K-12, community college, higher education, and non-profit groups. She is currently a telecommuting Senior Instructional Designer for the Penn State World Campus. Her primary research interests are games and simulations for education and how student perspectives of quality impact online course design.

\section{References}

Aleckson, J. (2010). Micro-collaboration: Team sharing to build highly interactive online activities. Paper presented at the 26th Annual Conference on Distance Teaching \& Learning. Madison, WI.

Available online at:

http://www.uwex.edu/disted/conference/Resource_library/proceedings/29659_10.pdf

Aleckson, J. \& Ralston-Berg, P. (2011). MindMeld: Micro-Collaboration between eLearning designers and instructor experts. Madison, WI: Atwood Publishing.

Bates, A. W. (1997). The impact of technological change on open and distance learning. Distance education, 18(1), 93-109.

Bates, A.W. (2007). Developing a strategic plan for E-Learning in a polytechnic. In Bullen, M. and Janes, D. (eds.) Making the Transition to E-Learning: Strategies and Issues. Ideas Group, Hershey, PA.

Davis, A., Little, P., \& Stewart, B. (2004). Developing an infrastructure for online learning. Theory and practice of online learning, 97-114.

Deubel, P. (2003, September 15). Learning from reflections - issues in building quality online courses. Online Journal of Distance Learning Administration, 6 (3). Retrieved from http://www.westga.edu/ distance/ojdla/fall63/deubel63.html

Dziuban, C., Hartman, J., Moskal, P., Sorg, S., \& Truman, B. (2004). Three ALN Modalities: An institutional perspective. In J. Bourne \& J. C. Moore (Eds.), Elements of Quality Online Education: Into the Mainstream (pp. 127-148). Needham, MA: Sloan Center for Online Education.

Ellis, A. \& Phelps, R. (2000). Staff development for online delivery: A collaborative, team based action learning model. Australian Journal of Educational Technology, 16(1), 26-44. Retrieved from http://www.ascilite.org.au/ajet/ajet16/ellis.html

Grant, M.R., (2012). Instructional competencies matched with designer skills: symbiotic relationships in an E-Learning ecosystem. Presented at the University Professional and Continuing Education Association Annual Conference. Portland, OR.

Khan, B. H. (2004). The people-process-product continuum in E-Learning: the E-Learning p3 model. EDUCATIONAL TECHNOLOGY-SADDLE BROOK THEN ENGLEWOOD CLIFFS NJ-, 44(5), 33-40.

Khan, B. (2005). Managing E-Learning strategies: Design, delivery, implementation and evaluation. Hershey, PA: Information Science Publishing. 
Meyer, J. D., \& Barefield, A. C. (2010). Infrastructure and administrative support for online programs. Online Journal of Distance Learning Administration, 13(3). http://www.westga.edu/ distance/ojdla/Fall133/meyer barfield133.html

Northcote, M., Seddon, J., \& Brown, P. (2011). Benchmark yourself: Self-reflecting about online teaching. Education Papers and Journal Articles. Paper 34. Retrieved from http://research.avondale.edu.au/cgi/viewcontent.cgi?article=1034\&context=edu_papers

Quality Matters Program. (2013). Higher education program. Retrieved from https://www.qualitymatters.org/higher-education-program

Ralston-Berg, P., \& Gordy, B. (2002). Mission impossible: How to design an online course without a team. In Annual Conference on Teaching and Learning Proceedings. Madison, WI.

Ralston-Berg, P., McCaffrey, D., \& Kmetz, K. (2012, October). Collaborating for quality: A discussion of approaches to course design and development. Panel discussion presented at the 4th Annual QualityMatters (QM) Conference on Quality Assurance in Online Learning, Tucson, AZ.

Reid, I. C. (1999). Beyond models: developing a university strategy for online instruction. Journal of Asynchronous Learning Networks, 3(1), 19-31.

Reilly, J. Vandenhouten, C., Gallagher-Lepak, S., \& Ralston-Berg, P. (2012). Faculty development for ELearning: A multi-campus community of practice (COP) approach. Journal of Asynchronous Learning Networks, 16(2), 99-110.

Sixl-Daniell, K., Williams, J.B. \& Wong, A. (2006). A quality assurance framework for recruiting, training (and retaining) virtual adjunct faculty. Online Journal of Distance Learning Administration, 9(1). Retrieved from http://www.westga.edu/ distance/ojdla/spring91/daniell91.htm

Schnitzer, M. \& Crosby, L.S. (2003). Recruitment and development of online adjunct instructors. Online Journal of Distance Learning Administration, 6(2). Downloaded from: http://www.westga.edu/\%7Edistance/ojdla/summer62/crosby schnitzer62.html

Tyczkowski, B., Bauman, E., Gallagher-Lepak, S., Vandenhouten, C., \& Reilly, J. (2012). An interface design evaluation of courses in a nursing program using an E-Learning framework: A case study. In B. Khan (Ed.), User Interface Design for Virtual Environments (pp. 285-304). Hershey, PA: IGI Global.

Young, J. R. (1997). Rethinking the role of the professor in an age of high-tech tools. Chronicle of Higher Education, 44(6). 